\title{
Application of 3D-TO-2D garment design for atypical morphology: a design case for physically disabled people with scoliosis
}

\author{
DOI: 10.35530/IT.069.01.1377
}

YAN HONG

PASCAL BRUNIAUX

JUNJIE ZHANG

KAIXUAN LIU MIN DONG YAN CHEN

\section{REZUMAT - ABSTRACT}

\section{Aplicații ale proiectării îmbrăcămintei 3D-2D pentru morfologia atipică: un caz de proiectare pentru} persoanele cu dizabilități fizice cu scolioză

\begin{abstract}
Metoda de proiectare a îmbrăcămintei 3D-2D apare ca o soluție nouă pentru proiectarea și producția automată de îmbrăcăminte, în special pentru consumatorii cu morfologie atipică. În această lucrare s-a introdus un caz de aplicare a proiectării unui articol personalizat de îmbrăcăminte pentru persoanele cu dizabilități fizice, cu scolioză (PDPS), utilizând metoda de proiectare 3D-2D. Se propune un model îmbunătătit pentru a satisface cerința de automatizare a proiectării. Modelul propus se bazează pe evaluarea rezultatului de probare virtuală $3 D$ utilizând cunoștințele profesionale ale designerilor. Rezultatele cercetării arată că proiectarea îmbrăcămintei 3D-2D poate realiza în mod eficient o proiectare personalizată pentru morfologia atipică. De asemenea, utilizând evaluarea senzorială, cunoștințele profesionale de design pot fi aplicate pe deplin pentru a controla spațiul tehnic $2 D$ al proiectării îmbrăcămintei pe baza percepției rezultatului de probare virtuală a îmbrăcămintei $3 D$.
\end{abstract}

Cuvinte-cheie: morfologie atipică, proiectare virtuală, 3D-2D, proces pe bază de cunoștințe

Application of 3D-to-2D garment design for atypical morphology: a design case for physically disabled people with scoliosis

$3 D$-to-2D garment design method emerges as a novel design solution for automatic garment design and production, especially for consumers with atypical morphology. In this paper, we introduced an application case of designing a personalized garment for physically disabled people with scoliosis (PDPS) using 3D-to-2D garment design method. A pattern modification model is proposed in order to satisfy the requirement of design automation. The proposed modification model is based on the evaluation of the $3 D$ virtual try-on result using the professional knowledge of the designers. Research results indicate that $3 D$-to-2D garment design can effectively realize personalized design for atypical morphology. Also, using sensory evaluation, professional design knowledge of the designers can be fully applied to control the 2Dtechnical space of garment design based on the perception of $3 D$ garment virtual try-on result.

Keywords: atypical morphology, virtual design, 3D-to-2D, knowledge-based process

\section{INTRODUCTION}

With the development of 3D laser body scan and surface reconstruction technology, designing a garment directly on a 3D scanned body using virtual reality and 3D CAD technology emerges as a novel design solution for fashion industry. Currently, the 3D method consists of several design phases, which include 3D scanning, digitalized 3D body modeling, 3D garment generation, interactive 3D garment surface modeling and pattern design [1]. Compared with traditional design method such as traditional 2D-to-3D method, virtual reality based $3 D-t o-2 D$ design method is proved to be able to effectively satisfy the personalized garment design for atypical morphology [2]. However, 3D garment simulation is rather time costing and requires of high-level technical support of the software operation. What is more, due to the diversity of garment style, it is difficulty to define a systematic design rule for designing ready-to-wear products of all kind of styles using 3D-to-2D design method [3]. To solve this problem, in our previous study, we developed an interactive virtual try-on based 3D garment block design for physically disabled people of scoliosis type (PDPS) [1]. A personalized garment block is designed for PDPS with controlled wearing ease. Using this block, 2D garment patterns of the desired ready-to-wear products can be extended from the proposed garment block pattern. In this paper, based on previous study, we introduced an application case of designing a ready-to-wear garment using the garment block design from 3D-to-2D design method in order to validate the applicability of 3D-to-2D design method. Using personalized garment block, all kinds of garment style can be realized very fast in 2D environment, which can be easily controlled by designers compared with designing in 3D environment [5-6]. In this research, a perception-based pattern modification model is proposed on the basis of a collaborative design process. Perceptual data of consumers on the desired product is extracted and analyzed by the knowledge and experience of designers using an interactive procedure. Sensory analysis (or sensory evaluation) is a scientific discipline that makes use of human senses (sight, smell, taste, touch and hearing) 
for the purpose of evaluating consumer products based on certain evaluation criteria. Using a sensory evaluation method, 3D virtual try-on result can be accessed by designers through touch and observation based on their experience and professional knowledge. By utilizing a pre-defined pattern modification model, pattern can be modified automatically based on the evaluation results.

\section{EXPERIMENTAL WORK}

In this research, a 3D-to-2D design based personalized garment design process is proposed. Figure 1 presents the proposed design process. The proposed design process begins with a personalized garment block design from 3D-to-2D design method. Using the flattened garment block pattern, extension of the desired garment pattern can be realized considering the garment style and fabric property. Then, using a $3 \mathrm{D}$ virtual try-on procedure, a fast validation of the proposed pattern can be realized using virtual fabrics. Designers and consumers can be invited to participate in the evaluation section. His/her sensory evaluation result based on the pre-defined evaluation criteria will be input into a predefined knowledge based pattern modification rule base. Pattern modification plans can be generated automatically. Using this method, 2D technical space of pattern making can be easily controlled by 3D perception space using 3D virtual try-on. Also, new design rule will be generated as a new input into the proposed knowledge based pattern modification rule base in order to enhance the precision of the automatic pattern modification. As a knowledge-based learning system, the more designers and consumers involved in the decision making of the design process, higher satisfaction of the design solution can be ensured.

In order to realize the proposed design process, two experiments are proposed. In Experiment I, garment patters for ready-to-wear garment products are extended from a set of garment block pattern designed by a 3D-to-2D design method. Fabric properties are tested in order to simulate corresponding virtual fabric. Based on the extended patters and virtual fabric, a $3 \mathrm{D}$ virtual try-on is performed for further evaluation. In Experiment II, an automatic pattern modification rule base is defined. First, a set of evaluation criteria is defined, then, corresponding pattern modification rules are discussed by pattern designers using their professional design knowledge.

\section{Experiment I Production pattern design and 3D virtual try-on}

In this study, a personalized garment block for a physically disabled lady with scoliosis from our previous study is applied [1]. Using the proposed block patterns, the design case of a shirt can be obtained. The specifications design sheet in figure 2 describes the requirements for the design elements of the shirt designed by designers in this study.

Then, several extension and sizing procedure are performed in oder to obtian the desired garment style in figure 2. Professional knowledge of pattern designers isutilized to support this process. These operations are:

Step 1: Adding $1 \mathrm{~cm}$ to the side seam, center front and back lines for all patterns, creating the buttonholes.

Step 2: Drawing vertical lines from the lowest armhole points to create the new side seam lines, increasing the length of the new side seam lines by $24.5 \mathrm{~cm}$ from the waistlines and drawing new lines vertical to the side seam lines to be the new bottom lines.

Step 3: Symmetrizing the back waist dart with the same value in the opposite direction of the original dart, while the symmetrical line is the end of dart legs (The two lines that converge at a predetermined point on the pattern.).

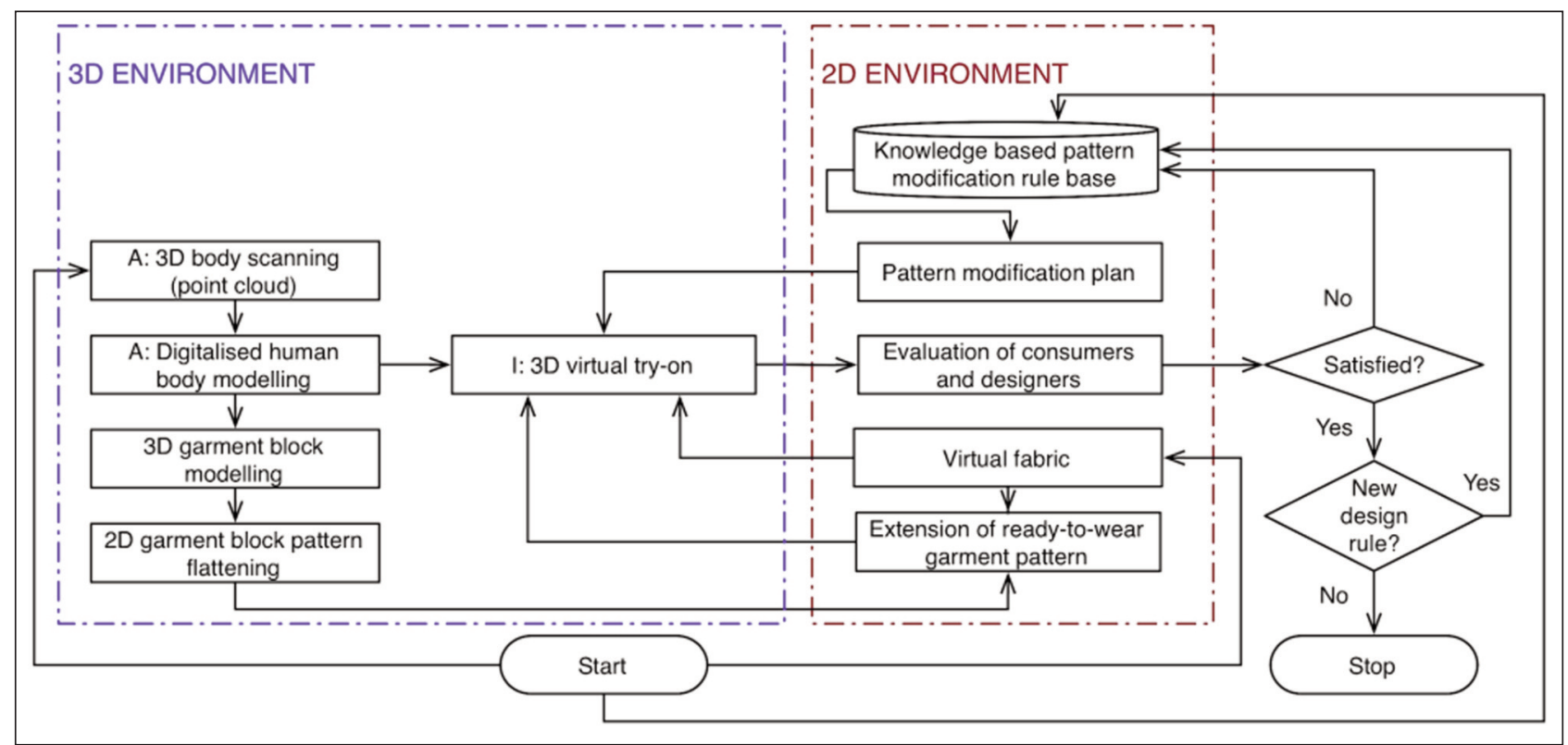

Fig. 1. Research framework and working process of the proposed design process 


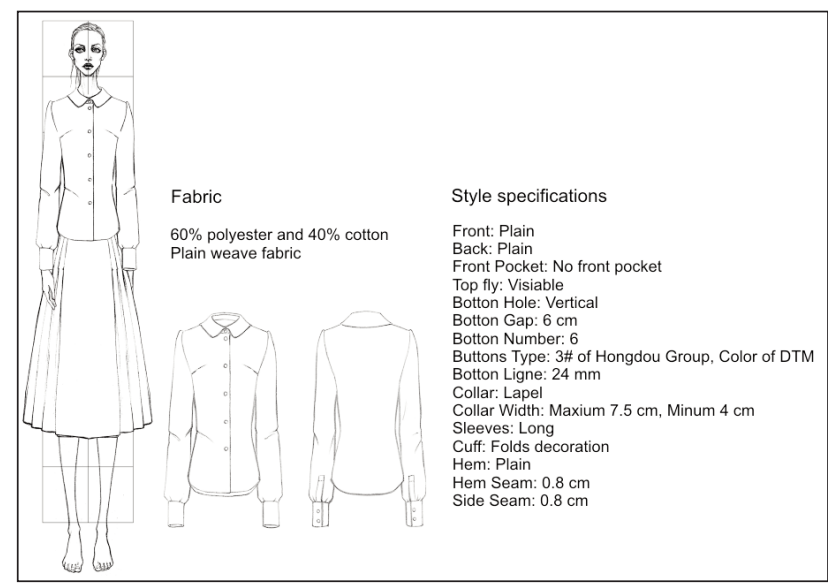

Fig. 2. The design specifications sheet of the shirt

Step 4: Drawing a straight line to be the grainline (the center of the sleeve from top of curved top of the sleeve top to wrist level) of the sleeve, measuring the front and back armholes of the previous patterns, recording the measurements on the patterns for future reference, adding the front and back armhole measurements together and divide the value into four to be the cap height of the sleeve (the distance from widest line of the sleeve to the top at the grainline).

Step 5: Determining the length of the cuff as $20 \mathrm{~cm}$ (add $4 \mathrm{~cm}$ to the girth of artifice as $16 \mathrm{~cm}$ ), the width of cuff as $5 \mathrm{~cm}$.

Step 6: Determining the height of the stand collar as $3 \mathrm{~cm}$ and the height of the top collar as $4 \mathrm{~cm}$.

By adding seam allowances and using Modaris software also with the virtual fabric, the production patterns of the designed shirt are finished, shown in figure 3 .

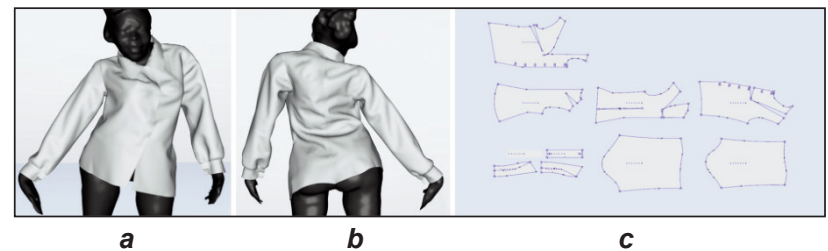

Fig. 3. Design result in both front and back views, and the corresponding garment patterns

\section{Experiment II Evaluation and adjustment of the 3D try-on perception}

In this study, a session of sensory evaluation is realized by a group of fashion designers and pattern makers in order to quantitatively characterize the 3D virtual try-on perception of the shirt designed using the customized block patterns [7-8]. Then, the adjustment of the shirt patterns can be realized in the 2D technical space according to the sensory evaluation results on the performance of the finished shirt in the 3D virtual try-on space. Evidently, the key issue of this adjustment is to set up a model characterizing the relationship between the technical space and 3D virtual product perceptual space. This model will permit to generate the appropriate technical parameters of the garment according to the desired values of

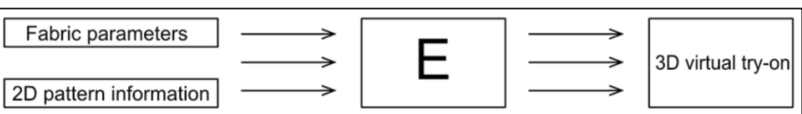

Fig. 4. Model characterizing the relation between technical parameters and perception on 3D virtual garment try-on

sensory evaluation on the effects of $3 D$ virtual garment try-on (figure 4).

In this study, the aim of identifying the shirt fit in 3D virtual try-on evaluation is to generate normalized sensory descriptors, which constitute the common communication language between fashion designers, pattern makers and garment consumers [9-11]. Five experienced fashion designers are involved in the evaluation. The parameters of the fabric chosen by the designers as described in the design specifications sheet as well as the finished production patterns constitute the inputs to the Modaris software for realizing 3D virtual try-on. The style and design elements in the design specifications sheet can generate a common idea of the designers for the evaluation. In this context, the sensory evaluation results on the fit of the designed shirt, given by different designers, can be very close to each other. The sensory evaluation procedure used in our study is described as follows.

Each trained designer generates an exhaustive list of categories describing the shirt fit performance according to his/her professional knowledge. The three most relevant categories describing the key positions of the shirt have been selected: "Overall image", "fit in width" and "fit in details". Then, a list of descriptors describing the shirt fit in different categories is generated by the designers using their garment design knowledge and pattern design knowledge.

After that, there is a section reducing redundant descriptors and those irrelevant to the fit of a shirt, by performing a "round table" discussion inside the panellists. This step leads to the generation of 8 normalized descriptors describing the apparel fit performance (table 1). For each descriptor, a scale of five evaluation scores, ranging from -2 to 2 , is also

Table 1
SENSORY DESCRIPTORS DESCRIBING THE APPAREL FIT PERFORMANCE

\begin{tabular}{|l|l|}
\hline Categories & Apparel fit performance descriptor \\
\hline \multirow{2}{*}{$D_{A}:$ Overall image } & $D_{A 1}$ Overall fit \\
\cline { 2 - 2 } & $D_{A 2}$ Length \\
\hline \multirow{4}{*}{$D_{B}:$ Fit in width } & $D_{B 1}$ Waist fit \\
\cline { 2 - 2 } & $D_{B 2}$ Breast fit \\
\cline { 2 - 2 } & $D_{B 3}$ Hem fit \\
\hline \multirow{4}{*}{$D_{C}:$ Fit in details } & $D_{C 1}$ Shoulder fit \\
\cline { 2 - 2 } & $D_{C 2}$ Neck fit \\
\cline { 2 - 2 } & $D_{C 3}$ Arm hole fit \\
\hline
\end{tabular}


EVALUATION SCORES AND THE CORRESPONDING SEMANTICS

\begin{tabular}{|c|c|c|c|c|c|}
\hline Scores & $-\mathbf{2}$ & $-\mathbf{1}$ & $\mathbf{0}$ & $\mathbf{1}$ & $\mathbf{2}$ \\
\hline Semantics & Very tight/small & A little tight/small & Perfect & A little loose/big & Very loose/big \\
\hline
\end{tabular}

obtained. "-" means that the garment is tight or small related to the body shape while "+" means in the opposite direction (big or loose). 0 is a perfect fit on the wearer. Each score of the scale is defined semantically in table 2 .

By repeating the evaluation two times and taking the average of the evaluation scores for each sensory descriptor, we finally obtain a matrix composed of all evaluation scores.

The adjustment of the current patterns will be realized using a rule-based model characterizing the relation between evaluations values on the shirt fit (perceptual space) and modifications of garment patterns (technical space). It has been established by exploiting the common professional knowledge of pattern makers through a round table discussion

Table 3

\begin{tabular}{|c|c|c|}
\hline \multicolumn{3}{|c|}{$\begin{array}{c}\text { MODIFICATION RULES BASED ON EVALUATION } \\
\text { RESULT }\end{array}$} \\
\hline $\begin{array}{c}\text { Sensory descriptors } \\
\text { on garment fit }\end{array}$ & $\begin{array}{l}\text { Rule } \\
\text { code }\end{array}$ & Modification rules \\
\hline \multirow{3}{*}{$\mathrm{D}_{\mathrm{A} 1}$ Overall fit } & $\mathrm{D}_{\mathrm{A} 1 \mathrm{a}}$ & $\begin{array}{l}\text { Change the length } \\
\text { of waistline }\end{array}$ \\
\hline & $\mathrm{D}_{\mathrm{A} 1 \mathrm{~b}}$ & $\begin{array}{l}\text { Change the length } \\
\text { of breast line }\end{array}$ \\
\hline & $\mathrm{D}_{\mathrm{A} 1 \mathrm{c}}$ & $\begin{array}{l}\text { Change the length } \\
\text { of shoulder line }\end{array}$ \\
\hline $\mathrm{D}_{\mathrm{A} 2}$ Length & $\mathrm{D}_{\mathrm{A} 2 \mathrm{a}}$ & $\begin{array}{l}\text { Change the length of } \\
\text { the garment }\end{array}$ \\
\hline \multirow{2}{*}{$D_{B 1}$ Waist fit } & $\mathrm{D}_{\mathrm{B} 1 \mathrm{a}}$ & $\begin{array}{l}\text { Change the cut } \\
\text { of side seam }\end{array}$ \\
\hline & $\mathrm{D}_{\mathrm{B} 1 \mathrm{~b}}$ & $\begin{array}{l}\text { Change the value } \\
\text { of waist dart }\end{array}$ \\
\hline \multirow{2}{*}{$D_{B 2}$ Breast fit } & $\mathrm{D}_{\mathrm{B} 2 \mathrm{a}}$ & $\begin{array}{l}\text { Change the cut } \\
\text { of side seam }\end{array}$ \\
\hline & $\mathrm{D}_{\mathrm{B} 2 \mathrm{~b}}$ & $\begin{array}{l}\text { Change the value } \\
\text { of breast dart }\end{array}$ \\
\hline $\mathrm{D}_{\mathrm{B} 3}$ Hem fit & $\mathrm{D}_{\mathrm{B} 3 \mathrm{a}}$ & $\begin{array}{l}\text { Change the cut } \\
\text { of side seam }\end{array}$ \\
\hline \multirow{3}{*}{$\mathrm{D}_{\mathrm{C} 1}$ Shoulder } & $\mathrm{D}_{\mathrm{C} 1 \mathrm{a}}$ & $\begin{array}{l}\text { Change the slope } \\
\text { of shoulder line }\end{array}$ \\
\hline & $D_{C 1 b}$ & $\begin{array}{l}\text { Change the length } \\
\text { of shoulder line }\end{array}$ \\
\hline & $\mathrm{D}_{\mathrm{C} 1 \mathrm{c}}$ & $\begin{array}{l}\text { Change the width } \\
\text { of neckline }\end{array}$ \\
\hline \multirow{2}{*}{$\mathrm{D}_{\mathrm{C} 2} \mathrm{Neck}$} & $\mathrm{D}_{\mathrm{C} 2 \mathrm{a}}$ & $\begin{array}{l}\text { Change the width } \\
\text { of neckline }\end{array}$ \\
\hline & $\mathrm{D}_{\mathrm{C} 2 \mathrm{~b}}$ & $\begin{array}{l}\text { Change the depth } \\
\text { of neckline }\end{array}$ \\
\hline \multirow{2}{*}{$\mathrm{D}_{\mathrm{C} 3}$ Armhole } & $D_{C 3 a}$ & $\begin{array}{l}\text { Change the position } \\
\text { of sleeve top }\end{array}$ \\
\hline & $\mathrm{D}_{\mathrm{C3b}}$ & $\begin{array}{l}\text { Change the curvature } \\
\text { of the armhole }\end{array}$ \\
\hline
\end{tabular}

between these panellists. Five experienced pattern makers are involved in the production process. There are two steps for modelling the relationship:

Step 1: Identification of the shirt modification rules These rules will enable to determine the key points or key lengths of the shirt production patterns corresponding to each sensory descriptor in order to make the final shirt very close to the target wearing effect wished by the designers. The final modification rules provided by the pattern makers are given in table 3 . Normally, for each sensory descriptor, there are several alternative modification rules. However, in practice, only one rule is applied during the adjustment. One example is given below.

If we wish to modify "overall fit" $\left(D_{A 1}\right)$, then we can change the length of either waistline $\left(D_{A 1 a}\right)$, or breast line $\left(D_{A 1 b}\right)$ or shoulder line $\left(D_{A 1 c}\right)$.

Step 2: Identification of the new values of change for garment patterns

For each modification rule, the change of the identified key point or key length is determined according to the evaluation score of the corresponding sensory descriptor. The whole values of change of patterns related to all the modification rules, provided by the designers, are shown in table 4. For example, when applying the modification rule $\mathrm{D}_{\mathrm{A} 1 \mathrm{a}}$ related to the

Table 4

VALUES OF CHANGE FOR SHIRT PRODUCTION PATTERNS

\begin{tabular}{|c|c|c|c|c|c|}
\hline $\begin{array}{c}\text { Evaluation. } \\
\text { Scores }\end{array}$ & -2 & -1 & 0 & 1 & 2 \\
\hline $\mathrm{D}_{\mathrm{A} 1 \mathrm{a}}$ & $+8 \mathrm{~cm}$ & $+4 \mathrm{~cm}$ & 0 & $-4 \mathrm{~cm}$ & $-8 \mathrm{~cm}$ \\
\hline $\mathrm{D}_{\mathrm{A} 1 \mathrm{~b}}$ & $+8 \mathrm{~cm}$ & $+4 \mathrm{~cm}$ & 0 & $-4 \mathrm{~cm}$ & $-8 \mathrm{~cm}$ \\
\hline $\mathrm{D}_{\mathrm{A} 1 \mathrm{c}}$ & $+4 \mathrm{~cm}$ & $+2 \mathrm{~cm}$ & 0 & $-2 \mathrm{~cm}$ & $-4 \mathrm{~cm}$ \\
\hline $\mathrm{D}_{\mathrm{A} 2 \mathrm{a}}$ & $+4 \mathrm{~cm}$ & $+2 \mathrm{~cm}$ & 0 & $-2 \mathrm{~cm}$ & $-4 \mathrm{~cm}$ \\
\hline $\mathrm{D}_{\mathrm{B} 1 \mathrm{a}}$ & $+3 \mathrm{~cm}$ & $+1 \mathrm{~cm}$ & 0 & $-1 \mathrm{~cm}$ & $-3 \mathrm{~cm}$ \\
\hline $\mathrm{D}_{\mathrm{B} 1 \mathrm{~b}}$ & $+2 \mathrm{~cm}$ & $+1 \mathrm{~cm}$ & 0 & $-1 \mathrm{~cm}$ & $-2 \mathrm{~cm}$ \\
\hline $\mathrm{D}_{\mathrm{B} 2 \mathrm{a}}$ & $+3 \mathrm{~cm}$ & $+1 \mathrm{~cm}$ & 0 & $-1 \mathrm{~cm}$ & $-3 \mathrm{~cm}$ \\
\hline $\mathrm{D}_{\mathrm{B} 2 \mathrm{~b}}$ & $+2 \mathrm{~cm}$ & $+1 \mathrm{~cm}$ & 0 & $-1 \mathrm{~cm}$ & $-2 \mathrm{~cm}$ \\
\hline $\mathrm{D}_{\mathrm{B} 3 \mathrm{a}}$ & $+3 \mathrm{~cm}$ & $+1 \mathrm{~cm}$ & 0 & $-1 \mathrm{~cm}$ & $-3 \mathrm{~cm}$ \\
\hline $\mathrm{D}_{\mathrm{C} 1 \mathrm{a}}$ & $+4^{\circ}$ & $+2^{\circ}$ & 0 & $-2^{\circ}$ & $-4^{\circ}$ \\
\hline $\mathrm{D}_{\mathrm{C} 1 \mathrm{~b}}$ & $+3 \mathrm{~cm}$ & $+1 \mathrm{~cm}$ & 0 & $-1 \mathrm{~cm}$ & $-3 \mathrm{~cm}$ \\
\hline $\mathrm{D}_{\mathrm{C} 1 \mathrm{c}}$ & $+3 \mathrm{~cm}$ & $+1 \mathrm{~cm}$ & 0 & $-1 \mathrm{~cm}$ & $-3 \mathrm{~cm}$ \\
\hline $\mathrm{D}_{\mathrm{C} 2 \mathrm{a}}$ & $+3 \mathrm{~cm}$ & $+1 \mathrm{~cm}$ & 0 & $-1 \mathrm{~cm}$ & $-3 \mathrm{~cm}$ \\
\hline $\mathrm{D}_{\mathrm{C} 2 \mathrm{~b}}$ & $+3 \mathrm{~cm}$ & $+1 \mathrm{~cm}$ & 0 & $-1 \mathrm{~cm}$ & $-3 \mathrm{~cm}$ \\
\hline $\mathrm{D}_{\mathrm{C} 3 \mathrm{a}}$ & $+2 \mathrm{~cm}$ & $+1 \mathrm{~cm}$ & 0 & $-1 \mathrm{~cm}$ & $-2 \mathrm{~cm}$ \\
\hline $\mathrm{D}_{\mathrm{C} 3 \mathrm{~b}}$ & $+2 \mathrm{~cm}$ & $+1 \mathrm{~cm}$ & 0 & $-1 \mathrm{~cm}$ & $-2 \mathrm{~cm}$ \\
\hline & & & & \\
\hline
\end{tabular}




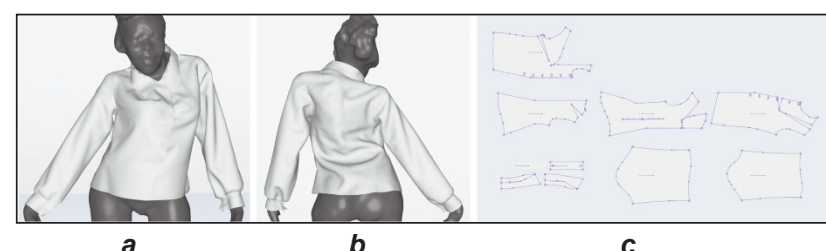

Fig. 5. Design result after modification in both front and back views, and the corresponding garment patterns

"overall fit", if the evaluation score is -1 (a little tight), then $4 \mathrm{~cm}$ will be added to the width of waistline in horizontal direction.

In practice, one modification rule and its corresponding pattern changing value can be arbitrarily selected and its try-on result can be quantitatively characterized using the sensory evaluation. If the adjustment result is not satisfying, another rule of the same sensory descriptor will be selected in order to generate a new try-on result. This procedure can be carried out repeatedly until finding the most relevant adjustment plan.

By using the previous two steps, we set up the relationship between 3D virtual shirt try-on results and 2D pattern parameters (key points and key lengths). This rule-based model permits to reach a desired perception of shirt fit by adjusting the 2D pattern parameters. In this study, the procedure of Design - Display - Evaluation - Adjustment with the model can be performed repeatedly until a satisfying design solution is obtained, as shown in figure 5. (Chen, Tao, Zeng, Koehl, \& Boulenguez-Phippen, 2015) (Chen et al. 2015) (Chen et al. 2015) [4] (Chen, Tao, Zeng, Koehl, \& Boulenguez-Phippen, 2015) (Chen, Tao, Zeng, Koehl, \& Boulenguez-Phippen, 2015) (Chen, Tao, Zeng, Koehl, \& Boulenguez-Phippen, 2015) (Chen, Tao, Zeng, Koehl, \& Boulenguez-Phippen, 2015) (Chen, Tao, Zeng, Koehl, \& Boulenguez-Phippen, 2015) $D_{A 2}$ Length, $D_{B 1}$ Waist fit, $D_{B 2}$ Breast fit, $D_{B 3}$ Hem fit, $D_{C 1}$ Shoulder fit and $D_{C 2}$ Neck fit of the initial pattern is modified using the rule based model based on the perception of the involved designers.

To validate the design result, following the design specifications sheet, the garment is produced following the garment patterns after modification. To evaluate the real shirt produced using the pattern modified as the evaluation results before, a fitting procedure is proposed. The fitting result is shown in figure 6 . As for the customer, the look and comfort of the shirt are perceived as fine during the fitting.

In order to validate the proposed design process, another group of designers are invited to compare the initial garment virtual try-on result and the final modified garment virtual try-on result using the evaluation criteria presented in table 1.

First, there is a training section about the purposed of the evaluation. Then both the initial garment virtual try-on result and the final modified garment virtual tryon are presented to the invited designer group. The invited designers are free to operate the computer to observe the virtual try-on results. Each of the invited

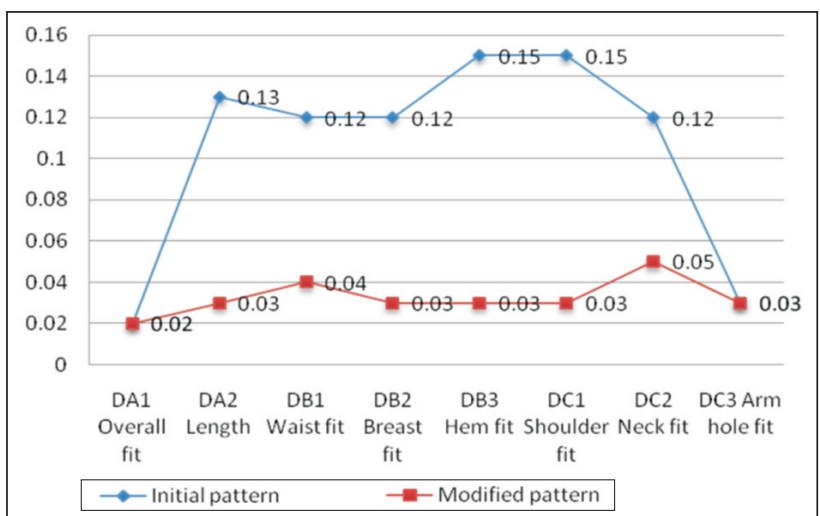

Fig. 6. Distances of aggregated evaluation results of all evaluation criteria to the degeree of "Perfect $(1.5,2,2.5)$ "

designers is assigned to finish the evaluation independently without any discussion with other designers.

\section{RESULTS AND DISCUSSION}

In order to quantify the evaluation degrees, a set of fuzzy numbers is assigned to each of the linguistic term. The involved evaluationlinguistic term and their corresponding fuzzy numbers are described in table 5 .

Table 5

\begin{tabular}{|c|c|}
$\begin{array}{c}\text { LiNGUISTIC RATING SCALE AND CORRESPONDING } \\
\text { FUZZY NUMBERS }\end{array}$ \\
\hline Linguistic values & TFNs \\
\hline Very loose/big & $(2.5,3,3.5)$ \\
\hline A little loose/big & $(2,2.5,3)$ \\
\hline Perfect & $(1.5,2,2.5)$ \\
\hline A little tight/small & $(1,1.5,2)$ \\
\hline Very tight/small & $(0.5,1,1.5)$ \\
\hline
\end{tabular}

Then, using the following equation to aggregate the evaluation result of all the involved designers:

$$
a_{i j}=\left(\frac{1}{m} \sum_{j=1}^{l} a_{i j h} t_{1}, \frac{1}{m} \sum_{j=1}^{1} a_{i j h} t_{2}, \frac{1}{m} \sum_{j=1}^{l} a_{i j h} t_{3}\right)
$$

Where $t_{1}, t_{2}, t_{3}$ correspond to the value of TFNs, and their values are taken according to table 3 [12-14].

Then, Euclidean distance of between all the aggregated evaluation results to the semantic degree "Perfect $(1.5,2,2.5)$ is calculated in order to measure the satisfaction of invited designers of both initial garment virtual try-on result and finial modified virtual try-on result, as presented in figure 6 . These distances indicate the satisfaction degree of each part of the virtual try-on result in terms of different evaluation criteria. Shorter distance indicates higher membership degree.

$D_{A 2}$ Length, $D_{B 1}$ Waist fit, $D_{B 2}$ Breast fit, $D_{B 3}$ Hem fit, $D_{C 1}$ Shoulder fit and $D_{C 2}$ Neck fit are less satisfactory compared to the initial pattern. Some modification should be performed on these parts, matching the designers' idea referring to Experiment II. 
Generally, the modified pattern is more "perfect" compared with the initial pattern, which indicates that the proposed Design - Display - Evaluation Adjustments procedure is able to help to reach a desired perception of shirt fit by adjusting the 2D pattern parameters using the proposed rule-based model. 2D pattern parameters (key points and key lengths) can be adjusted by the evaluation result of the 3D virtual try-on results.

\section{CONCLUSIONS}

In this paper, to validate the applicability of 3D-to-2D garment design method, we introduced an application case of designing a personalized garment for physically disabled people with scoliosis (PDPS) using a set of garment block pattern designed by a 3D-to-2D garment design method. The proposed design process begins with a personalized garment block design from 3D-to-2D design method. Desired garment patterns are realized by the extension of the previous garment block pattern considering both desired garment style and fabric properties. After that, using the proposed pattern and virtual fabric, a $3 \mathrm{D}$ virtual try-on can be realized and ensures a fast validation of the proposed pattern. Designers and consumers are able to participate in the evaluation section. Also, we defined a rule-based pattern modification model to validate the designer design idea. Based on sensory evaluation results, pattern modification plan can be generated. Though a validation experiment, it can be proved that, as knowledge based learning process, the proposed design process is able to ensure a high level of design satisfaction of consumers.

\section{BIBLIOGRAPHY}

[1] Yan Hong, Xianyi Zeng, Pascal Bruniaux, Kaixuan Liu. Interactive virtual try-on based three-dimensional garment block design for disabled people of scoliosis type, In: Textile Research Journal. 2016, vol. 72, issue 2, pp. $156-163$.

[2] Cupar, A., Development of classification methodology of perceptional surfaces in product design, In: Doctoral Dissertation, University of Maribor, Faculty of Mechanical Engineering, 2015.

[3] Kaixuan Liu, Edwin Kamalha, Jianping Wang, Tarun-Kumar Agrawal. Optimization design of cycling clothes' patterns based on digital clothing pressures, In: Fibers and Polymers. 2016, vol.17, issue 9, pp. 1522-1529.

[4] Yan Hong, Min Yang, Yan Chen. Development of clothing micro climate monitoring system for human physiological indexes, In: Journal of Textile Research. 2013, vol. 34, issue 1, pp. 96-100.

[5] Niculescu, C., Mielicka, E., Salistean, A., Napieralska, L., Popescu, G., \&Mocenco, A. Web portal for customized production of clothing for overweight and elderly people, In: IndustriaTextila, 2016, vol. 67, issue 3, p. 194.

[6] Rudolf, A., Cupar, A., Kozar, T., Stjepanović, Z. Study regarding the virtual prototyping of garments for paraplegics. In: Fibers and polymers, ISSN 1229-9197, May 2015, vol. 16, no. 5, pp. 1177-1192.

[7] Park C.K., Kang T.J. Objective evaluation of seam pucker using artificial intelligence Part II: Method of evaluating seam pucker, In: Textile Research Journal, 1999, vol. 69(11), pp. 835-845.

[8] Lau T.W., Hui P.C.L., Ng F.S.F., Chan K.C.C. A new fuzzy approach to improve fashion product development, In: Computers in Industry, 2006, vol. 57, pp. 82-92.

[9] Ries, al., Trout, J. (1985), Positioning: The battle of the mind, McGraw-Hill Companies.

[10] Olson, J.C., Jacoby, J. (1972), Cue Utilization in the quality perception process, In: Venkatesan, M. (Ed.): Proceedings of the Third Annual Conference of the Association for Consumer Research, Association for Consumer Research, Chicago, IL, pp. 167-179.

[11] Solomon, M.R. (2009), Consumer behaviour: buying, having, and being, Prentice Hall.

[12] Park S.W., Hwang Y.G., Kang B.C., Yeo S.W. Applying fuzzy logic and neural networks to total hand evaluation of knitted fabrics, In: Textile Research Journal, 2000, vol. 70(8), pp. 675-681.

[13] Takagi T., Sugeno M. Fuzzy identification of systems and its application to modeling and control, In: IEEE Transactions on Systems, Man, and Cybernetics, 1985, vol. 15(1), pp. 116-132.

[14] Tahal, I., Abdin, Y., Ebeid, S. Prediction of draping behavior of woven fabrics over double-curvature moulds using finite element techniques, In: International Journal of Material and Mechanical Engineering, 2012, vol. 1, pp. 25-31.

\section{Authors:}

YAN HONG ${ }^{1,2,3}$, PASCAL BRUNIAUX², JUNJIE ZHANG ${ }^{4}$, KAIXUAN LIU ${ }^{4}$, MIN DONG ${ }^{4}$, YAN CHEN ${ }^{4}$

${ }^{1}$ College of Textile and Clothing Engineering, Soochow University, Suzhou 215021, China

2 GEMTEX, ENSAIT, 2 allée Louise et Victor Champier, 59056 Roubaix Cedex 1, France

${ }^{3}$ Technical University of lasi, Dimitrie Mangeron Bd., 53, lasi - 700050, Romania

${ }^{4}$ Department of Mathematics and Computer, Wuhan University of Textile, Wuhan 430070, China

\section{Corresponding author:}

YAN HONG

e-mail: yannichonghk@gmail.com 